\title{
PENERAPAN MANAJEMEN STRATEGIK DENGAN ANALISIS SWOT PADA SMP NEGERI 4 KENDARI
}

\author{
Ambar Sri Lestari \\ Universitas Islam Negeri (UIN) Sunan Gunung Djati Bandung \\ JI. A.H. Nasution No. 105 Cibiru, Bandung, Jawa Barat, Indonesia 40614 \\ Email: ambarlestari@uinsgd.ac.id
}

\begin{abstract}
ABSTRAK
Tujuan penelitian adalah untuk mendeskripsikan secara jelas mengenai implementasi manajemen strategi pada SMPN 4 Kendari yang meliputi analisis perhitungan lingkungan internal dan eksternal. Lingkungan internal adalah lingkungan yang mempunyai pengaruh langsung pada oprasional lembaga pendidikan, seperti kurikulum, kesiswaan, tenaga pendidik dan kependidikan, sarana dan prasarana sebagai potensi dari sekolah itu sendiri, situasi persaingan, situasi pelanggan pendidikan, dan pengguna lulusan. Semuanya berpengaruh pada penentuan strategi yang diperkirakan mendukung sekolah mencapai tujuannya. Lingkungan eksternal merupakan berbagai kekuatan dan kondisi yang muncul diluar lingkungan sekolah yang meliputi perkembangan teknologi, pemerintah, lingkungan masyarakat dan sekolah sejenis sebagai tantangan global.
\end{abstract}

Katakunci: Implementasi, Manajemen Strategi, Lingkungan Internal dan Eksternal

\begin{abstract}
The aim of the study was to describe clearly the implementation of strategic management at Kendari 4 Public Middle School which included analysis of internal and external environmental calculations. Internal environment is an environment that has a direct influence on the operational of educational institutions, such as curriculum, student affairs, teaching staff and education, facilities and infrastructure as the potential of the school itself, competitive situation, educational customer situation, and graduate users. Everything influences the determination of the strategy which is expected to support the school to achieve its objectives. The external environment is a variety of strengths and conditions that arise outside the school environment which include the development of technology, government, community environment and similar schools as a global challenge.
\end{abstract}

Keywords: Implementation, Strategy Management, Internal and External Environment 


\section{PENDAHULUAN}

Keberhasilan penyelenggaraan pendidikan sangat ditentukan oleh kemampuan kepala sekolah dalam mengelola semua sumber daya yang ada di sekolah. Bahwa yang menjadi penentu keberhasilan suatu sekolah terletak pada kemampuan kepala sekolah dalam melaksanakan tugas-tugasnya. Tugas utama kepala sekolah sebagai pemimpin sekolah adalah menciptakan situasi belajar mengajar yang kondusif sehingga para guru dan siswa dapat melaksanakan kegiatan belajar mengajar dengan baik di lingkungan sekolahnya. Dalam sebuah lembaga pendidikan, peran kepala sekolah merupakan salah satu bagian yang sangat penting dalam sebuah organisasi atau lembaga sekolah. Karena peran kepala sekolah adalah pengerak utama yang dapat mendorong sekolah untuk mewujudkan visi dan misi sekolahnya (Muhaimin, 2013:196). Hal tersebut dapat dicapai melalui program-program yang dilaksanakan secara terencana dan bertahap termasuk mengenai perannya dalam meningkatkan kinerja guru.

Peran kepala sekolah juga menjadi strategis dan sifatnya krusial dalam tugas dan wewenang yang melekat pada jabatan seorang kepala sekolah. Mutu sekolah sangat dipengaruhi oleh mutu kepemimpinan kepala sekolah. Sekolah bermutu menjadi tuntutan dan kebutuhan stakeholder (pemangku kepentingan). Oleh karena itu hanya kepemimpinan yang baiklah dapat melakukan berbagai upaya agar tujuan pendidikan, baik tujuan pendidikan secara nasional, institusional maupun individual tercapai sebagaimana mestinya. Manajemen pendidikan yang diterapkan dilingkungan internal system persekolahan hanyalah sebagian dari tanggung jawab kepala sekolah sebagai manajer pendidikan. Para pengelola pendidikan (kepala sekolah) sebagai eksekutif modern saat ini harus mampu mengamati dan merespon segenap tantangan yang dimunculkan oleh lingkungan eksternal baik yang dekat maupun yang jauh.

Berdasarkan observasi awal yang dilakukan di SMP Negeri 4 Kendari, dapat dilihat bahwa sekolah tersebut mempunyai potensi yang telah dapat diakui kredibilitasnya dan tumbuh menjadi salah satu sekolah unggulan. Hal ini dapat terlihat dari peran serta kepala sekolah dalam peningkatan kinerja guru, letak sekolah yang strategis sehingga tercipta lingkungan belajar yang tertib dan nyaman, pemantauan terhadap peserta didik oleh guru yang berkelanjutan, peran serta dukungan orang tua murid dan masyarakat yang optimal. Salah satu cara yang dapat dilakukan agar hal tersebut dapat tercapai yaitu apabila sekolah tersebut mempunyai seorang pemimpin yang mampu membawa perubahan terhadap kinerja sekolah dengan strategi tertentu. Oleh sebab itu beberapa hal yang ingin diketahui adalah proses implementasi manajeman strategi di SMPN 4 Kendari.

Strategi dipahami bukan hanya sebagai "berbagai cara untuk mencapai tujuan (ways to achieve ends) melainkan mencakup pula penentuan berbagai tujuan itu sendiri. Sebagaimana dirumuskan oleh Chandler, strategi merupakan: "the determinationof long-term goals of an necessary for carrying out these goals". Strategi dipahami pula sebagai sebuah pola yang mencakup di dalamnya baik strategi yang direncanakan (intended strategy and deliberate strategy) maupun strategi yang pada awalnya tidak dimaksudkan oleh perusahaan (emerging strategy) tetapi menjadi strategi yang dipertimbangkan 
bahkan dipilih oleh perusahaan untuk diimplementasikan (realized strategy) (Ismail, 2012:64). Banyak sekali pengertian mengenai manajemen strategi namun pada prinsipnya sama yaitu menggabungkan berpikir strategis dengan fungsi-fungsi manajemen yaitu: perencanaan, penerapan dan pengawasan.

Wheelen dan Hunger mengemukaan manajemen strategik adalah serangkaian keputusan dan tindakan manajerial yang menentukan kinerja perusahaan dalam jangka panjang. Manajemen strategic meliputi pengamatan lingkungan, perumusan strategi (perencanaan strategic atau perencanaan jangka panjang), evaluasi dan pengendalian. Manajemen Strategi adalah sekumpulan keputusan dan tindakan yang menghasilkan perumusan (formulating) dan pelaksanaan (implementasi) rencana-rencana yang di rancang untuk mencapai sasaran-sasaran perusahaan (Husein, 2010:16).

1. Menurut Wahyudi manajemen strategic adalah suatu seni dan ilmu dari perumusan (formulating), penerapan (implementing), dan evaluasi (evaluating) keputusan-keputusan strategis antar fungsi-fungsi yang memungkinkan sebuah organisasi mencapai tujuan-tujuan masa mendatang (Akdon, 2011:5).

2. Manajemen Strategik menurut Flavel dan Williams (1996) adalah sebagai keseluruhan sistem manajemen, di manadi dalamn yang terkandung formulasi, implementasi dan evaluasi guna mencapai hasil yang realistis dan obyektif (Hassel, 2003:9).

3. Strategi sering kali dimulai dari apa yang dapat terjadi dan bukan dimulai dari apa yang terjadi (Thomas, 2013:61-62).

4. Strategi disusun dengan perencanaan-perencanaan organisasi dengan tahapan berupa analisis lingkungan internal dan eksternal (Jamaludin, 2017:270)

Manajemen strategis adalah seni dan ilmu penyusunan, penerapan, dan pengevaluasian keputusan-keputusan, manajemen strategis berfokus pada proses penetapan tujuan organisasi, pengembangan kebijakan dan perencanaan untuk mencapai sasaran, serta mengalokasikan sumber daya untuk menerapkan kebijakan dan merencanakan pencapaian tujuan organisasi (David, 2004: 56). Manajemen strategis mengkombinasikan aktivitas-aktivitas dari berbagai bagian fungsional suatu bisnis untuk mencapai tujuan organisasi. Jadi manajemen strategic yang dimaksud dalam penelitian ini adalah serangkaian kegiatan yang di mulai dari pengamatan lingkungan, perumusan (strategy formulating), penerapan (strategy implementing), dan evaluasi (strategy evaluating) di sekolah, yang di lakukan untuk meningkatkan kualitas proses pembelajaran sehingga dapat menghasilkan siswa-siswi yang berprestasi dibidangak ademik maupun non akademik.

Manajemen strategi semakin penting arti dan manfaatnya bahwa lingkungan perusahaan (organisasi) mengalami perubahan yang semakin cepat dan kompleks, dimana dibutuhkan suatu pemikiran strategi dari para pemimpin untuk mengelola perubahan yang ada dalam suatu strategi yang tepat dan handal sehingga keberhasilan manajemen strategi ditentukan oleh para manajer/pimpinannya. Dari berbagai lingkungan yang ada pada perusahaan, apabila adanya perubahan, tidak mustahil dapat memberikan kesempatan berusaha baru, tapi dapat pula mangancam kehidupan usaha lainnya. Selain itu, terdapat faktor internal yang meliputi, kondisi 
keuangan, struktur organisasi, kualitas dan kuantitas personil, fasilitas dan sarana, tujuan dan strategi masalalu. Dengan memadukan dan memperhatikan kesempatan-kesempatan $(\mathrm{O})$ dan ancaman-ancaman $(\mathrm{T})$ yang berasal dari lingkungan eksternal, baik sekarang maupun ramalan masa datang, dengan berbagai kekuatan-kekuatan (S) dan kelemahan- kelemahan (W) yang berasal dari lingkungan internal barulah disusun suatu strategi yang mantap. Dalam internal bisnis, kegiatan tersebut dianggap sebagai pengenalan situasi yang disebut "SWOT analisis". Analisis SWOT ini singkatan dari Strength, Weakness, Oppourtunities dan Threath. Dalam melakukan analisis lingkungan eksternal yang terdapat beberapa faktor (ekonomi, politik, sosial, teknologi, demografi, dan hukum) ini diperlukan sebuah tehnik yang baik agar informasi yang didapat utuh. Beberapa tehnik antara lain:

a) Tehnik pengumpulan informasi lisana dalam informasi yang didapat dengan cara mendengar, baik itu secara formal maupun non formal.

b) Tehnik pengumpulan imformasi tertulisatau dokumentasi adalahapa yang di ketahui dengan membaca informasi yang di sediakan oleh orang lain untuk berbagai tujuan. Misalnya, informasi surat kabar tentang perekonomian, politik dan lain-lain.

c) Tehnik memata-matai (spionase) yaitu berusaha untuk mengumpulkan informasi tentang pesaing yang potensial atau sesungguhnya.

d) Tehnik pengamatan langsung. Manajen puncak atau orangyang di tunjuk melakukan pengamatan langsung kepasar yang menjadi sasaran produk/ jasa kita.

e) Tehnik peramalan secara formal adalah meramalkan semua faktor lingkungan. Misalnya mengenai pandangan masyarakat terhadap pelayanan pendidikan dan sebagainya (Amirullah, 2000:28).

Ada empat elemen dasar yang digunakan oleh manajer untuk mengimplementasikan strategi. Empat elemen itu adalah struktur, kepemimpinan, kultur (budaya) dan system imbalan (motivasi). Uraian mengenai keempat elemen tersebut adalah sebagai berikut:

a. Struktur Organisasi

Dalam mengimplementasi strategi melalui struktur organisasi berguna untuk mengkomunikasikan kegiatan/tugas bawahan. Struktur organisasi adalah sebagai suatu sistem/jaringan kerja terhadap tugas-tugas, sistem pelaporan dan komunikasi yang menghubungkan secara bersama pekerjaan individual dan kelompok. Oleh karena itu, sebuah struktur organisasi hendaknya mengalokasikan pekerjaan melalui bagian-bagian pekerjaan dan menyediakan koordinasi dari hasil-hasil kinerja sehingga sasaran organisasi terlaksana dengan baik. Untuk struktur organisasiyaitu menurut penulis, menggunakan strukturorganisasi lini-staf karena pembagian tugas yang begitu jelas dan memberikan kesempatan kepada karyawan dan guru untuk mengembangkan dirinya. Struktur organisasi adalah pola tentang hubungan antara berbagai komponendan bagian organisasi.Pada organisasi formal struktur direncanakan danmerupakan usaha sengaja untuk menetapkan pola hubungan antar komponen, sehingga dapat mencapai sasaran secara efektif (Yulianti dan Hermawan, 2015: 99). 
b. Kepemimpinan Organisasi

Kepemimpinan memiliki posisi yang penting dalam suatu organisasi. Suatu organisasi yang tidak memiliki kepemimpinan yang kuat dapat dipastikan organisasi tersebut akan mudah mengalami kemunduran. Tanpa kepemimpinan yang efektif suatu organisasi akan lemah dan memiliki masalah yang serius (Hermawan dan Ghazali, 2017: 2). Kepemimpinan organisasi, suatu konsep yang merupakan satu elemen penting dari implementasi strategi yang efektif maka, struktur organisasi memberikan kerangka menyeluruh bagi implementasi strategi. Kepemimpinan dan kultur organisasi merupakan fenomena yang saling bergantung. Setiap aspek dari kepemimpinan akhirnya membantu membentuk kultur organisasi. Sebaliknya, kultur organisasi yang sudah ada dapat sangat mempengaruhi efektifitas seorang pemimpin. Eratnya kesaling bergantungan ini akan terlihat jelas.

c. Kultur Organisasi

Kultur (budaya) organisasi adalah sekumpulan asumsi penting (seringkali tidak diungkapkan) yang dianut oleh semua anggota suatu organisasi. Setiap organisasi memiliki budaya sendiri. Kultur suatu organisasi serupa dengan kepribadian seseorang tak wujud (intangible) tetapi selalu ada yang memberikan makna, arah dan dasar bertindak.

d. Sistem Imbalan (motivasi)

Pelaksanaan strategik pada akhirnya bergantung pada anggota organisasi secara individual, utamanya para manajer kunci. Dan memotivasi serta mengharga iprestasi individu dan unit organisasi yang baik merupakan bahan penting dalam implementasi strategi yang efektif.

\section{METODE}

Metode yang dilakukan dalam penelitian ini adalah metode kualitatif dengan dasar mekanisme kerangka analisis lingkungan internal dan eksternal SMPN 4 Kendari, proses manajemen strategi, perhitungan analisis swot yang analisis swot yang dikembangkan menjadi strategi S-O, strategi S-T, dan strategi W-T yang kemudian diimplementasikan dalam manajemen sekolah. Penelitian ini dilaksanakan di SMPN 4 Kendari selama 4 bulan mulai bulan Agustus hingga bulan Oktober 2018. Penelitian ini difokuskan pada penerapan manajemen strategi di SMPN 4 Kendari dalam meningkatkan prestasi akademis siswa SMPN 4 Kendari. Sumber data atau informasi yang digunakan dari penelitian ini antaralain kepala sekolah, wakil kepala sekolah bidang kurikulum, dan bidang kesiswaan.

Data dalam penelitian ini dikumpulkan menggunakan instrument berupa wawancara yang merupakan teknik pengumpulan data tentang persepsi atau pendapat sumber informasi mengenai implementasi manajemen strategi. Observasi adalah teknik yang digunakan untuk merekam proses penerapan manajemen strategi seperti proses implementasi manajemen strategi, maupun data faktor lingkungan eksternal dan internal yang digunakan sekolah sebagai alat formulasi dalam implementasi manajemen strategi, proses pengambilan keputusan hingga penerapan keputusan kedalam manajemen sekolah. Studi dokumentasi, merupakan pengumpulan data melalui dokumen-dokumen seperti teori-teori, dan referensi-referensi yang dapat melengkapi data penelitian terkait dengan implementasi manajemen strategi. 


\section{HASIL DAN PEMBAHASAN}

\section{A. Profil Sekolah SMP Negeri 4 Kendari}

SMP Negeri 4 Kendari merupakan salah satu sekolah menengah pertama yang terdapat di Kota Kendari di Jln. Jenderal Ahmad Yani, Kelurahan Bonggoeya, Kec. Wua-wua Kota Kendari. Yang didirikan pada tahun 10-011997. Indikator minat masuk SMP Negeri 4 Kendari beberapa tahun terakhir menunjukkan animo masyarakat sangat besar, SMP Negeri 4 Kendari termasuk salah satu sekolah menengah pertama terfavorit yang ada di Kendari. SMP Negeri 4 Kendari memiliki kondisi ruangan belajar yang cukup baik, dilengkapi dengan ruang laboratorium, ruang perpustakaan, ruangan OSIS, Ruangan BK, dan Mesjid. Dalam penyelenggaraan bidang pendidikan di SMP Negeri 4 Kendari juga tidak terlepas dari berbagai kendala dan permasalahan yang dihadapi, diantaranya:

1. Kurangnya atau terbatasnya sarana prasarana pembelajaran, sehingga kegiatan belajar mengajar tidak berjalan dengan optimal.

2. Sumber daya manusia memerlukan pembinaan dan wawasan teknologi.

3. Tenaga pendidik dan tenaga kependidikan terdapat kelebihan dan kekurangan.

4. Desakan pengaruh era globalisasi membutuhkan sarana dan prasarana yang bermuatan teknologi tinggi.

Di sisi lain peningkatan dan pemenuhan sarana dan prasarana pembelajaran masih perlu mendapatkan perhatian yang cukup serius, terutama pengadaan komputer hal ini terkait dalam pelaksaan Ujian Nasional Berbasis Computer namun sarana yang tidak memadai. Dilain pihak kemampuan tenaga kependidikan untuk mengembangkan tugas-tugasnya masih memerlukan pelatihan-pelatihan yang lebih intensif dan efektif.

1. Gambaran Umum SMP Negeri 4 Kendari

\begin{tabular}{|c|c|c|c|c|c|}
\hline 1 & Nama Sekolah & \multicolumn{4}{|c|}{ SMP NEGERI 4 KENDARI } \\
\hline 2 & NPSN & \multicolumn{4}{|c|}{40402606} \\
\hline 3 & Jenjang Pendidikan & \multicolumn{4}{|c|}{ SMP } \\
\hline 4 & Status Sekolah & \multicolumn{4}{|c|}{ Negeri } \\
\hline 5 & Alamat Sekolah & \multicolumn{4}{|c|}{ Jln. Jenderal Ahmad Yani } \\
\hline & RT / RW & 3 & / & 1 & \\
\hline & Kode Pos & \multicolumn{4}{|c|}{93118} \\
\hline & Kelurahan & \multicolumn{4}{|c|}{ Bonggoeya } \\
\hline & Kecamatan & \multicolumn{4}{|c|}{ Kec. Wua-Wua } \\
\hline & Kabupaten/Kota & \multicolumn{4}{|c|}{ Kota Kendari } \\
\hline & Provinsi & \multicolumn{4}{|c|}{ Prop. Sulawesi Tenggara } \\
\hline & Negara & \multicolumn{4}{|c|}{ Indonesia } \\
\hline 6 & Posisi Geografis & \multicolumn{3}{|c|}{-4.006092} & Lintang \\
\hline & & \multicolumn{3}{|c|}{122.4992} & Bujur \\
\hline \multicolumn{6}{|c|}{ 2. Data Pelengkap } \\
\hline 7 & SK Pendirian Sekolah & \multicolumn{4}{|c|}{$: \quad 0437 / 0 / 1977$} \\
\hline 8 & Tanggal SK Pendirian & \multicolumn{4}{|c|}{\begin{tabular}{l|l}
$:$ & $1977-10-01$ \\
\end{tabular}} \\
\hline 9 & Status Kepemilikan & \multicolumn{4}{|c|}{ Pemerintah Daerah } \\
\hline 10 & SK Izin Operasional & \multicolumn{4}{|c|}{ 135/A/1/1977 } \\
\hline
\end{tabular}




\begin{tabular}{|c|c|c|c|}
\hline 11 & Tgl SK Izin Operasional & $:$ & 1977-05-26 \\
\hline 12 & Kebutuhan Khusus Dilayani & : & Tidak ada \\
\hline 13 & Nomor Rekening & : & $001.02 .01 .186210-2$ \\
\hline 14 & Nama Bank & : & BANK SUL-TRA \\
\hline 15 & Cabang KCP/Unit & : & $\begin{array}{l}\text { PROV. SULAWESI } \\
\text { TENGGARA }\end{array}$ \\
\hline 16 & Rekening Atas Nama & : & SMPN 04 KENDARI \\
\hline 17 & MBS & : & $\mathrm{Ya}$ \\
\hline 18 & Luas Tanah Milik (m2) & $:$ & 12101 \\
\hline 19 & Luas Tanah Bukan Milik (m2) & : & 0 \\
\hline 20 & Nama Wajib Pajak & : & $\begin{array}{l}\text { BEND. SLTP NEGERI } 4 \\
\text { KENDARI }\end{array}$ \\
\hline 21 & NPWP & : & $1.84292 \mathrm{E}+11$ \\
\hline \multicolumn{4}{|c|}{ 3. Kontak Sekolah } \\
\hline 20 & Nomor Telepon & : & 0401-3191866 \\
\hline 21 & Nomor Fax & : & $0401-3195822$ \\
\hline 22 & Email & : & smpnegeri4kdi@yahoo.co.id \\
\hline 23 & Website & : & http://smpn4kendari.sch.id \\
\hline \multicolumn{4}{|c|}{ 4. Data Periodik } \\
\hline 24 & Waktu Penyelenggaraan & $:$ & Pagi \\
\hline 25 & Bersedia Menerima Bos? & : & Bersedia Menerima \\
\hline 26 & Sertifikasi ISO & : & Belum Bersertifikat \\
\hline 27 & Sumber Listrik & : & PLN \\
\hline 28 & Daya Listrik (watt) & : & 18300 \\
\hline 29 & Akses Internet & : & Lainnya \\
\hline 30 & Akses Internet Alternatif & : & \\
\hline \multicolumn{4}{|c|}{ 5. Data Lainnya } \\
\hline 31 & Kepala Sekolah & $:$ & Drs. MUH. SALEH, M.Pd \\
\hline 32 & Operator Pendataan & : & Lukman \\
\hline 33 & Akreditasi & 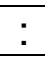 & $\mathrm{A}$ \\
\hline 34 & Kurikulum & : & Kurikulum 2013 \\
\hline
\end{tabular}

2. Visi Misi SMP Negeri 4 Kendari

Visi dan Misi SMP Negeri 4 Kendari:

Visi: Mewujudkan sekolah unggul, berprestasi, berwawasan IPTEK, berlandaskan IMTAG, dan memiliki disiplin yang tinggi.

Misi SMP Negeri 4 Kendari:

1) Meningkatkan koordinasi dan menciptakan suasana kondusif bagi warga sekolah dan masyarakat yang memiliki akhlak serta disiplin tinggi.

2) Melaksanakan inovasi pembelajran yang bermakna, kompetitif dan demokratis melalui pembelajaran aktif, kreatif, dan menyenangkan.

3) Melaksanakan bimbingan belajar secara efektif dan berkesinambungan, sehingga siswa berkembang secara optimal sesuai ppotensi yang dimiliki.

4) Melaksanakan kompetensi pendidik dan tenaga kependidikan secara berkesinambungan. 
5) Menumbuhkan semangat keunggulan secara intensif kepada seluruh warga sekolah sehingga dapat berprestasi pada tingkat Sekolah, Kabupaten/Kota, Provinsi, dan Nasional.

6) Menyediakan media pembelajaran bahasa inggris agar warga sekolah terampil berkomunikasi bahasa inggris.

7) Mengembangkan pengetahuan dan keterampilan dalam pemanfaatan media teknologi informasi dan computer untuk pengelolaan administrasi dan pembelajaran.

8) Menumbuhkan penghayatan terhadap ajaran agama yang dianut sehingga menjadi cermin kepribadian dalam beraktifitas dan bertindak.

9) Melaksanakan pembinaan bakat dan minat olahraga serta kesenian secara berkesinambungan.

10)Mewujudkan berbagai kegiatan ekstrakurikuler dan pengembangan diri.

11)Meningkatkan sarana dan prasarana pendukung pendidikan yang lengkap dalam lingkungan sekolah yang rindang dan asri.

3. Deskripsi Penyusunan Rencana Strategis

Penyusunan Rencana strategis SMPN 4 Kendari dilandasi oleh: 1). Pancasila sebagai landasan ideal; 2). Undang-Undang dasar 1945 sebagai landasan konstitusional; dan 3) Landasan Operasional, meliputi: a). Ketetapan MPR No. IV/MPR/1999 tentang GBHN; b) Undang-Undang No.22 tahun 1999 tentang Pemerintah Daerah; c) Undang-Undang No. 25 tahun 1999 tentang Perimbangan Keuangan antara Pemerintah pusat dan Daerah; d) UndangUndang No. 20 tahun 2003 tentang Sistem Pendidikan Nasional. Peraturan Pemerintah, diantaranya: a. Nomor 28 Tahun 1990 tentang Pendidikan Dasar; b. Nomor 29 Tahun 1990 tentang Pendidikan Menengah; c. Peraturan Pemerintah No. 25 tahun 2000 tentang Kewenangan Pemerintah dan Propinsi Sebagai Daerah Otonom; d.Nomor 19 Tahun 2005 tentang Standar Nasional Pendidikan, dan terkahir Surat Keputusan Menteri Pendidikan Nasional, diantaranya: a. Nomor. 44/U/2002 tentang Dewan Pendidikan dan Komite Sekolah; b. Nomor 122/U/2001 tentang Rencana Strategis Pembangunan; c. Nomor: 20 Tahun 2000 tentang Organisasi Perangkat Daerah.

Setiap institusi professional secara managerial tentu harus membuat suatu dasar yang akan dijadikan sebagai patokan dalam melaksanakan program kerja baik secara personal maupun sistemik, berdasarkan asumsi tersebut maka SMP Negeri 4 Kendari berupaya semaksimal mungkin untuk membuat suatu perencanaan yang strategis dalam rangka mendukung kebijakan dan tujuan pendidikan nasional. Rencana Strategis (Renstra) SMP Negeri 4 Kendari disusun dengan maksud menyediakan sebuah dokumen perencanaan yang akan dijadikan acuan dalam penyusunan program dan kegiatan tahunan pendidikan (2016/2017 s.d 2020/2021). Renstra SMP Negeri 4 Kendari adalah dokumen perencanaan strategis yang menjabarkan semua permasalahan pendidikan, indikasi-indikasi pencapaian target, dan kegiatan yang dilaksanakan untuk memecahkan permasalahan pendidikan secara terencana dan bertahap.

Secara umum Renstra akan menjadi tolok ukur penilaian pertanggungjawaban pada setiap akhir tahun anggaran SMP Negri 4 Kendari kepada stakeholder. Oleh karenanya Renstra SMP Negeri 4 Kendari adalah rencana 4 (empat) tahunan dari tahun 2016-2020 (tahun pelajaran (2016/2017 
s.d 2020/2021) yang menggambarkan visi, misi, tujuan, sasaran, kebijakan program, dan kegiatan pendidikan. Dengan demikian Renstra disusun melalui proses secara sistematis, konsisten dan berkelanjutan dari pengambilan keputusan dengan memanfaatkan kondisi, potensi, efisiensi, dan efektivitas penyelenggaraan pendidikan, yang pada akhirnya dapat memberikan sikap akuntabilitas kinerja yang bertumpu pada pencapaian keberhasilan KBM/PBM. Proses Penyusunan Rencana Strategis SMP Negeri 4 Kendari dilaksanakan dengan mengikuti alur pikir dengan mempertimbangkan hasil analisis lingkungan strategis terhadap kondisi umum, dan kendala-kendala yang dihadapi, serta mempertimbangkan program pembangunan daerah khususnya bidang pendidikan di Kota Kendari.

4. Tujuan Rencana Strategis

Tujuan disusunnya Renstra ini dimaksudkan untuk mengarahkan seluruh dimensi kebijakan pendidikan di SMP Negeri 4 Kendari, baik internal maupun eksternal, sebagai pedoman dalam:

a. Memudahkan seluruh jajaran SMP Negeri 4 Kendari dalam menentukan prioritas program dan kegiatan tahunan, pendidikan yang akan dibiayai dari APBS secara terpadu, terarah dan teratur.

b. Menggambarkan tentang kondisi pendidikan di SMP Negeri 4 Kendari dan mengarahkan seluruh kegiatan serta tujuan untuk mewujudkan visi dan misi pendidikan di SMP Negeri.

c. Sebagai pedoman evaluasi bagi jajaran pengelola SMP Negeri 4 Kendari untuk memahami dan menilai arah kebijakan sasaran program-program operasional tahunan pendidikan dalam rentang periode empat tahun (2016-2020).

5. Sasaran Rencana Strategis

Renstra ini mempunyai sasaran sebagai berikut:

a. Terformulasikan visi, misi, tujuan dan arah kebijakan pendidikan serta menetapkan fokus bidang kegiatan pengembangan dari tahun 20162020 sebagai prioritas utama pendidikan.

b. Terealisasinya program-program pendidikan dengan memperhatikan dan memanfaatkan kondisi, potensi, dan kendala serta faktor-faktor penentu eberhasilan Pendidikan.

6. Program dan Kegiatan Pendidikan

Secara umum strategi diarahkan untuk menyikapi seluruh program dan kegiatan yang dirumuskan, diantaranya:

a. Meningkatkan komitmen seluruh warga sekolah.

b. Meningkatkan kualitas pembelajaran dengan strategi.

c. Peningkatan kemampuan profesionalisme guru, melalui pelatihan, penataran, workshop dan efektifitas wadah MGMP.

d. Mengembangkan kurikulum muatan local.

e. Mengembangkan kualitas dan kuantitas fasilitas pembelajaran dengan strategi.

f. Merenovasi dan menambah lapangan olahraga.

g. Pengadaan sarana dan prasarana laboratorium Komputer.

h. Menata lingkungan agar lebih tertata rapi, nyaman dan menyenangkan.

i. Meningkatkan pembinaan siswa melalui penyaluran bakat dan prestasi dalam bidang olah raga dan seni. 
j. Mengembangkan penilaian dengan strategi.

k. Melaksanakan strategi peniliaian yang variatif.

I. Melaksanakan penilaian yang transparan, akuntabel, dan demokratis.

7. Kebijakan Pendidikan

Untuk memacu perkembangan pendidikan di SMP Negeri 4 Kendari perlu diidentifikasi faktor-faktor penentu keberhasilan tersebut dengan memperhatikan analisis lingkungan berupa sumber daya dan sumber dana yang di dukung peraturan-peraturan dan kebijakan-kebijakan serta keterlibatan masyarakat dalam mencapai Visi dan Misi SMP Negeri 4 Kendari adalah:

a. Guru mampu berinovasi dalam mengembangkan media pembelajaran yang inovatif, kreatif.

b. Keberhasilan guru dalam melakukan pembelajaran dikelas dapat tercermin dari keaktifan siswa.

c. Dukungan pemerintah Kota Kendari dalam melaksanakan MBS, Kurikulum 2013 serta pelaksanaan UNBK.

d. Teratasinya kinerja kelembangaan, keorganisasian dan keadministrasian yang masih lemah sebagai upaya meningkatkan kualitas pendidikan.

e. Terciptanya hubungan yang baik antara pihak sekolah dengan orang tua siswa.

\section{B. Analisis Lingkungan SMP Negeri 4 Kendari}

1. Analisis Faktor Internal Lingkungan SMP Negeri 4 Kendari

Analisis lingkungan internal dalam hal ini bertujuan untuk mengindentifikasi dan menjelaskan faktor-faktor yang menjadi kekuatan dan kelemahan SMP Negeri 4 Kendari.

a. Strenght (Kekuatan)

1) Tidak terdapat pungutan biaya dari siswa.

2) Guru memberikan motivasi dengan mengembangkan metode pembelajaran dan siswa juga cukup antusias terhadap pembelajaran dan ekstrakurikuler.

3) Fasilitas perpustakaan dan laboratorium komputer dengan kelengkapan buku dan computer untuk praktek.

4) Pendekatan dan metode mengajar guru yang bervariasi

5) Hubungan yang baik antara guru dengan guru ataupun dengan siswa.

b. Weakness (Kelemahan)

1) Keadaan guru masih terdapat guru honorer.

2) Rekrukmen guru dan staff yang tidak sesuai dengan kebutuhan.

3) Penerimaan siswa pindahan belum ada tes masuk.

4) Sarana dan prasarana yang belum memadai.

Beberapa aspek yang tercakup dalam lingkungan internal diantaranya:

a. Kurikulum

Kepala sekolah SMP Negeri 4 Kendari, mengatakan bahwa kami disini telah menerapkan kurikulum 2013. Kurikulum adalah pedoman yang digunakan dalam penyelenggaraan suatu pendidikan, kurikulum yang digunakan di SMP Negeri 4 Kendari adalah kurikulum 2013 sesuai dengan kebijakan pemerintah khususnya kemendikbud. Sebagaimana diketahui guru adalah salah satu komponen utama dalam pendidikan, seharusnya pemerintah dapat 
merencanakan penyelenggaraan diklat kurikulum 2013 secara merata, baik kepada sekolah swasta maupun sekolah negeri sehingga diperoleh kesiapan menyeluruh dalam penerapannya. Guru-guru di SMP Negeri 4 Kendari berbekal pada sosialisasi berusahan untuk memahami kurikulum 2013 lewat pemahaman pribadi dan bertukar pikiran antar guru, kurikulum 2013 cukup menyita waktu dalam hal pengelolaan nilai. Hal ini dikarenakan kurikulum 2013 memiliki lebih banyak aspek penilaian dibanding kurikulum sebelumnya.

Langkah-langkah apa yang dilakukan oleh wakasek (Wakil Bidang Kurikulum, wawancara tanggal 12 Agustus 2018) pengembangan mutu terkait dengan masih adanya masalah dalam proses pembelajaran oleh seorang guru. Terkait dengan hal tersebut ada berbagai peluang yang kita amati dalam melakukan langkah-langkah yang kami tetapkan, pertama yaitu kita melihat peluang dari jumlah pengajar yang hampir semua sudah berpendidikan S2, dan terkait tantangan yang ada yaitu terkait dengan kurikulum 2013 dalam implementasi kurikulum. Kemudian terkait dengan implementasi manajamen strategik yang dilakukan oleh kepala sekolah baru, kalau saya melihat kepala sekolah ini sudah melakukan perubahan sedikit demi sedikit yang mana contohnya hasil rapat dengan para guru langsung disosialisasikan sesuai dengan kerja struktural sesuai pengorganisasian dimana kepala sekolah mempunyai sifat manajerial yang sangat baik. Untuk menjaga atensi kinerja guru kepala sekolah melakukan supervisi selama ini masih berjalan, kalau "saya sendiri sebagai ketua MGMP PAI di amanahkan untuk mensupervisi beberapa guru yang di amanahkan oleh pimpinan dan sejauh ini berjalan lancar. Dalam bidang kurikulum itu hanya ada 3 aspek dalam rencana strategi yaitu: persiapan pembelajaran, pelaksanaan pembelajaran, dan penilaian pembelajaran. Ketika ketiga aspek ini sudah berhasil diterapkan maka rencana strategi sudah sesuai dengan idealnya, sekalipun ada hambatan tetap berjalan dengan baik.

b. Kesiswaan

Hal yang pertama kami analisis yaitu untuk kesiswaan di SMP Negeri 4 Kendari tidak terdapat pungutan biaya mulai dari biaya pendaftaran masuk di SMP Negeri 4 Kendari sampai selesai. Sebagaimana yang dikatakan oleh kepala sekolah bahwa di sekolah ini tidak ada yang namanya komite, begitupun dengan biaya lainnya (Kepala sekolah, wawancara tanggal 20 Agustus 2018). Hal ini berdasarkan dengan sistem penerimaan siswa baru di SMP Negeri 4 Kendari menggunakan pendaftaran sistem online para siswa baru mendaftar jalur online. Kemudian untuk pelaksanaan ujian nasional pada tahun pelajaran 2016/2017 kemarin, untuk pertama kalinya dilaksanakan ujian nasional berbasis computer. Selain itu untuk kegiatan rutinitas yang dilaksanakan setiap hari jumat yaitu kegiatan keagamaan seperti Yasinan dan kegiatan kerja bakti. Untuk menjaga kedisiplinan siswa maka para siswa dibekali dengan buku control dengan jumlah 100 poin.

Untuk mengontrol setiap siswa dalam hal kedisiplinanya misalnya jika siswa terlambat maka siswa akan dikurangi point 5 dan pengurangan point tersebut ditulis dibuku kontrol. SMP Negeri 4 Kendari juga masih menerima siswa pindahan dari sekolah lain hal ini lebih dipertegas oleh kepala sekolah yang mengatakan bahwa: "selama sekolah ini masih bisa menerima kami akan menerimanya dari sekolah manapun itu" (Kepsek, wawancara tanggal 10 
September 2018). Selain itu guru-guru mampu memberikan motivasi yang tinggi kepada siswa-siswanya dengan mengembangkan metode pembelajaran dan siswa yang cukup antusias dalam pembelajaran ekstrakurikuler. Dengan adanya motivasi guru dan siswa maka tercipta pula hubungan yang baik antara guru dengan guru ataupun antara guru dan siswa hal ini sesuai dengan yang dikatakan oleh kepala sekolah "bahwa kami disini sangat menjaga hubungan baik antara guru dengan guru meskipun terdapat guru yang berbeda agama namun kami sangat menjaga hubungan baik ini, begitu pula dengan siswasiswa" (Kepsek, wawancara tanggal 22 September 2018). Selain itu pula untuk meningkatkan prestasi belajar siswa guru-guru melakukan pendekatan dan metode mengajar yang bervariasi. Sebagaimana yang dikatakan oleh satu guru matematika "anak-anak itu biasanya mengalami kebosanan atau kejenuhan dalam belajar dikelas sehingga kami para guru dituntut utnuk mampu memberikan pendekatan ataupun dengan metode pembelajaran yang bervariasi ketika kami mengajar (Guru Matematika, wawancara tanggal 4 Oktober 2018)" dengan dukungan fasilitas perpustakaan yang menyediakan kelengkapan buku-buku pelajaran siswa serta dilengkapi pula dengan laboratorium komputer.

c. Tenaga pendidik dan kependidikan

Keadaan guru di SMP Negeri 4 Kendari sudah sebagian besar guru PNS namun masih terdapat beberapa orang guru honorer. Adapun data terkait dengan kelebihan dan kekurangan mengenai aparatur sipil negara, sebagai berikut:

Tabel 1. Keadaan Tenaga Pendidik

\begin{tabular}{ll} 
No & \multicolumn{1}{c}{ Guru Mata Pelajaran } \\
1 & Kepala Sekolah \\
2 & Bagian Tata Usaha \\
3 & PPKN \\
4 & Pendidikan Agama \\
5 & Bahasa Indonesia \\
6 & Matematika \\
7 & IPA \\
8 & IPS \\
9 & Bahasa Inggris \\
10 & Seni Budaya \\
11 & Penjasorkes \\
12 & Prakarya \\
13 & Bimbingan Konseling
\end{tabular}
Jumlah Aparatur Sipil Negara

$\begin{array}{cccc}\text { Seharusnya } & \text { Ada } & \text { Lebih } & \text { Kurang } \\ 1 & 1 & & \\ 15 & 8 & & 7 \\ 6 & 6 & & \\ 4 & 3 & & 1 \\ 9 & 8 & & 1 \\ 8 & 8 & & \\ 9 & 11 & 2 & \\ 6 & 6 & & \\ 6 & 7 & 1 & \\ 4 & 3 & & 1 \\ 4 & 3 & & 1 \\ 3 & 3 & & \\ 8 & 3 & & 5\end{array}$

Berdasarkan data di atas maka dapat disimpulkan bahwasannya tenaga pendidik dan kependidikan di SMP Negeri 4 Kendari masih terdapat beberapa mata pelajaran yang memiliki kelebihan guru dan kekurangan guru. Hal ini nampak bahwa proses rekrumen guru dan staff yang tidak sesuai dengan kebutuhan. Sehingga membuat para guru yang mengajar dengan mata pelajaran yang gurunya tidak mencukupi maka mengajar diluar batas jam mengajar yang seharusnya. Dengan demikian dapat dikatakan tenaga pendidik dan kependidikan belum efektif dan efisien. 


\section{d. Sarana dan Prasarana}

Berdasarkan data yang kami (Wakil bidang sarana prasarana, wawancara tanggal 5 Oktober 2018) dapatkan, sarana dan prasarana di SMP Negeri 4 Kendari ini belum cukup lengkap/memadai. Sebagaimana yang di katakana oleh kepala sekolah bahwa "Keadaan sarana dan prasaran yang terdapat disekolah kami memang belum begitu memadai salah satunya yaitu ketersedian computer masih sangat terbatas begituh pun dengan lapangan olahraga yang belum memadai". Hal ini didasarkan karena bantuan yang diberikan tidak setiap tahun dan hanya bantuan dari pusat diadakan berjenjang. Hal ini terbukti dengan pernyataan beberapa guru dan juga kepala sekolah yang mengungkapkan bahwa mereka memang masih belum mempunyai computer yang lengkap sehingga saat pelaksanaan ujian berbasis online ini digunakan, mereka terpaksa meminjam laptop dari para siswa dan mengadakan rapat terlebih dahulu agar setiap orang tua siswa mengetahui dan mau mengizinkan anak-anaknya untuk membawa laptop agar proses ujian berjalan dengan baik.

\section{Analisis Faktor Lingkungan Eksternal SMP Negeri 4 Kendari}

Analisis lingkungan eksternal dalam hal ini bertujuan untuk mengindentifikasi dan menjelaskan factor-faktor yang menjadi peluang dan ancaman bagi pendidikan SMP Negeri 4 Kendari. Kajian eksternal pada hakekatnya adalah analisis dan evaluasi atas kondisi di luar SMP Negeri 4 Kendari.

a. Opportunity (Peluang)

1) Kesesuain sarana dan Prasarana Sekolah dengan tuntutan perkembangan IPTEK.

2) SMP Negeri 4 Kendari mendapatkan dukungan pemerintah dalam melengkapi sarana dan prasarana.

3) SMP Negeri 4 Kendari tidak terdapat bantuan sponsor dalam pengembangan sekolah.

4) Tuntutan masyarakat terhadap lulusan yang berkualitas.

5) SMP Negeri 4 mendapat dukungan orang tua yang tinggi.

b. Ancaman

1) Kemajuan Teknologi computer dan informatika. Belum terlalu maksimal karena kurangnya guru yang mengajar khusus TIK

2) Lembaga pendidikan sejenis, banyak SMP-SMP lainnya yang juga favorit di kota Kendari.

3) Lingkungan social sekolah hal ini dapat dilihat dengan lapangan olahraga yang belum memadai.

Beberapa aspek yang tercakup dalam lingkungan eksternal diantaranya:

a. Pekembangan IPTEK (IImu pengetahuan dan Teknologi)

Sebagaimana dikatakan oleh kepala SMP 4 Kendari bahwa: "Dalam menyikapi perkambangan IPTEK tentunya kita memiliki berbagai persepsi akan hal itu. Kita bisa saja menganggap hal tersebut sebagai ancaman bagi kita, tetapi juga bisa kita anggap sebagai sarana pendukung dalam manajemen sekolah. Karena IPTEK datang dengan membawa dua dampak yaitu positif dan negatif. Untuk positifnya sendiri kami dapat rasakan pada kemudahan kita dalam proses pembelajaran misalnnya dengan menggunakan berbagai media dalam menyampaikan materi pembelajaran dikelas seperti komputer/laptop, 
dan infocus, tentu hal itu akan memberi dampak positif bagi kita. Namun di sisi lain, dampak negatif dari IPTEK itu sendiri juga tak bisa dibantahkan. Hal ini dapat kami lihat dari bagaimana para siswa sekarang lebih senang menggunakan android daripada belajar. Waktu mereka banyak habis terbuang untuk hal-hal yang tidak bermanfaat. Oleh karena itu, untuk mengatasinya kami mengeluarkan peraturan untuk tidak diperbolehkan membawa handphone disekolah. Selain itu, dari perkembangan IPTEK juga kami melarang para siswa untuk membawa kendaraan pribadi ke sekolah. Hal ini karena disamping mereka masih belum cukup usia untuk berkendara sendiri, ini juga kami lakukan untuk meminimalisir kecelakaan". Dari hasil wawancara di atas, maka dapat kami simpulkan bahwa di SMPN 4 kendari dalam menyikapi perkembangan IPTEK mereka telah melakukan tindakan preventif untuk meminimalisir dampak negatif dari iptek itu sendiri. Hal ini dilakukan selain untuk menjaga dan melindungi siswa juga sebagai bentuk kepedulian sekolah kepada seluruh siswa untuk berhati-hati dalam menggunakan berbagai teknologi yang selalu berkembang, hal ini tentunya merupakan tantangan besar bagi lembaga tersebut.

b. Pemerintah

Berdasarkan hasil wawancara dengan kepala sekolah SMP Negeri 4 Kendari mengatakan bahwa: "Respon pemerintah dengan sekolah sudah sangat baik karena adanya hubungan kerja dengan pemerintah, salah satu wujudnya yaitu dengan adanya bantuan dana pembiayaan berupa dana BOS dengan jumlah yang lumayan besar". Berdasarakan hal tersebut maka dapat disimpulkan bahwa pembiayaan operasional di tanggungkan oleh pemerintah dan dukungan pemerintah dalam melengkapi sarana dan prasarana SMP Negeri 4 Kendari. Hal ini sebagaimana yang dikatakan oleh wakil kepala sekolah bagian sarana prasarana mengatakan bahwa "pengadaan computer baru-baru ini sebanyak 20 unit yang dimana computer sebelumnya hanya berjumlah 23 buah, dan sekarang telah berjumlah 43 unit computer dan itu artinya satu ruangan telah terpenuhi untuk mempersiapkan UNBK selanjutnya". Sehingga dapat dikatakan bahwa dukungan pemerintah dalam melengkapi sarana dan prasarana sudah sangat baik.

\section{c. Lingkungan Masyarakat}

Berdasarkan hasil wawancara dengan kepala sekolah SMPN 4 Kendari, beliau mengatakan bahwa: "untuk lingkungan masyarakaat, kami cukup memiliki perhatian yang baik dari mereka. Hal ini dapat kami lihat dari partisipasi masyarakat dalam berbagai program-program sekolah yang kami lakukan. Diantaranya, ketika kami melakukan UNBK tahun ajaran 2016/2017, pada saat itu kami memiliki banyak keterbatasan sarana seperti computer. Dimana peserta yang mengikuti UNBK pada saat itu berjumlah \pm 400 siswa, sedangkan pada saat itu kami hanya memiliki 23 kompuer. Namun berkat adanya partisipasi dari masyarakat, hal itu sedikit kami dapat atasi sebab mereka mau meminjamkan computer pribadi mereka. Selain itu, para orang tua siswa juga tidak pernah keberatan dalam memberikan partisipasi dana dalam proses pengadaan barang sekolah. Dan yang terkhir salah satu peran masyarakat yang terpenting dalam lembaga ini adalah, mereka senantiasa memasukkan anak mereka ke sekolah ini. Sehingga setiap tahunnya jumlah siswa di sekolah kami selalu meningkat." Dari hasil wawancara diatas, maka 
dapat kami simpulakan bahwa peran lingkungan masyarakat dalam membantu dan memberikan partisipasi pada lembaga pendidikan tersebut sangat besar dan besarnya tuntutan masyarakat terhadap lulusan yang berkualitas. Hal ini dapat dilihat dari kontribusi positif yang mereka berikan. Kemudian SMP Negeri 4 Kendari tidak menerima sponsor dari suatu perusahaan ataupun dari yayasan, hal ini tentunya menjadi peluang tersendiri bagi keberadaan sekolah tersebut.

\section{d. Sekolah Sejenis}

Berdasarkan wawancara kami dengan kepala sekolah beliau mengatakan bahwa: "di kota Kendari ini terdapat SMP-SMP lainnya yang juga difavoritkan, selain itu pula karena fasilitas sekolah, kami tentunya masih belum memadai salah satunya yaitu lapangan olahraga kemudian persaingan masuk SMP Negeri yaitu banyak persaingan lulusan yang terjadi antar SMP-SMP yang diminati dalam test masuk SMP Negeri". Berdasarkan hal tersebut dapat dikatakan bahwa hal itu merupakan tantangan bagi SMP Negeri 4 Kendari karena mereka merupakan saingan bagi SMP Negeri 4 Kendari.

\section{Perhitungan IFAS/EFAS SMP Negeri 4 Kendari}

Faktor-faktor

Strategi Internal

Kekuatan (S)

1) Pembiyaan

2) Motivasi guru dan siswa

3) Fasilitas perpustakaan dan laboratorium Komputer

4) Pendekatan metode mengajar guru yang bervariasi

5) Hubungan yang baik antara guru dengan guru ataupun dengan siswa

Jumlah $\mathbf{S}$

Kelemahan (W)

1) Keadaan Guru
Tabel 2. Perhitungan IFAS SMP Negeri 4 Kendari

\section{Bobot Rating Bobot X Keterangan} Rating

$0,10 \quad 3 \quad 0,30$

$0,15 \quad 3 \quad 0,45$

0,45 Memberikan motivasi yang tinggi dengan mengembangkan metode pembelajaran dan siswa juga cukup antusias terhadap pembelajaran dan ekstrakurikuler Kelengkapan buku dan computer untuk praktek

Guru menggunaka pendekatan dan metode pembelajaran yang bervariasi Sangat menjaga hubungan antar sesama dan mejunjung tinggi sikap tolerensi

\section{1,8}

$0,10 \quad 3 \quad 0,30$

Masih terdapat beberapa guru yang honorer 


$\begin{array}{lllll}\text { 2) Rekrutmen guru } & 0,10 & 3 & 0,30 & \begin{array}{l}\text { Rekrutmen guru dan staf } \\ \text { yang tidak sesuai dengan } \\ \text { dan staf }\end{array} \\ \begin{array}{lllll}\text { kebutuhan } \\ \text { 3) Penerimaan } \\ \text { siswa pindahan }\end{array} & 0,10 & 3 & 0,30 & \begin{array}{l}\text { Penerimaan siswa } \\ \text { pindahana Belum ada tes } \\ \text { masuk } \\ \text { Belum cukup memadai }\end{array} \\ \begin{array}{l}\text { 4) Gedung Sekolah } \\ \text { Jumlah W }\end{array} & \begin{array}{l}0,10 \\ \mathbf{0 , 4}\end{array} & 3 & \begin{array}{l}0,30 \\ \mathbf{1 , 2}\end{array} & \\ \text { JUMLAH S+W } & \mathbf{1 , 0 0} & & \mathbf{3 , 0} & \end{array}$

Simpulan:

Berdasarkan dari bobot masing-masing butir kekuatan dan kelemahan yang ada pada matrik diatas dapat disimpulkan bahwa antara kekuatan yang dimiliki oleh SMP Negeri 4 Kendari ini hampir seimbang. Hal ini dapat dijadikan pelajaran untuk pihak sekolah bahwa kekuatan yang ada kurang begitu dimaksimalkan untuk meminimalisir kelemahan yang ada. Diharapkan dari analisis ini sekolah akan terus berusahan dan meningkatkan kekuatan sekolah yang telah dimiliki dengan seoptimal mungkin agar kelemahan yang ada dapat teratasi.

\section{Eksternal}

Peluang (0)

1) Kesesuain sarana dan Prasarana Sekolah dengan tuntutan perkembangan IPTEK

2) Dukungan pemerintah dalam melengkapi sarana dan prasarana

3) Sponsor/perusaha 0,10 an/ yayasan

4) Tuntutan masyarakat terhadap lulusan yang berkualitas

5) Dukungan orang tua yang tinggi
Tabel 3. Perhitungan Efas SMP Negeri 4 Kendari

\section{Bobot Rating Bobot $X$ Komentar}

\section{Rating}

0,60

Karena sarana dan

prasarana merupakan

kekuatan artinya

kerjasama pengadaan

sarana dan prasarana

dan pemanfaatan yang

ada harus di

kembangkan terus.

Sekolah dapat mengajukan proposal kepada pemerintah perlu dilakukan untuk melengkapi sarana dan prasarana

Tidak terdapat bantuan sponsor dalam pengembangan sekolah Masyarakt menharapkan setelah selesai dari SMP ini diharapkan dapat melanjutkan ke jenjang yang lebih tinggi dan berkualitas Terbukti dengan orang tua mendaftarkan test masuk SMP Negeri 4 
JUMLAH

Ancaman ( $T$ )

1) Kemajuan

Teknologi

computer dan

informatika

pendidikan sejenis

3) Persaingan

masuk SMP

Negeri

4) Lingkungan socia sekolah
0,6

$0,05 \quad 3 \quad 0,15$

1,95

Kendari sangat banyak.

Belum terlalu maksimal karena kurangnya guru yang mengajar khusus TIK

Banyak SMP-SMP lainnya yang juga favorit di kota Kendari

0,30 Banyak persaingan lulusan yang terjadi antra SMP yang diminati dalam tertest masuk SMP Negeri Memiliki lapangan olahraga yang belum memadai

$\begin{array}{lll}\text { JUMLAH T } & 0,35 & 1,05 \\ \text { JUMLAH O+T } & 0,95 & \mathbf{3 , 2}\end{array}$

Simpulan:

Berdasarkan tabel di atas maka dapat dilihat dari butir peluang sarana dan prasarana adalah peluang yang paling besar dimiliki oleh SMP Negeri 4 Kendari meskipun ini masih jauh dari tertinggi, tetapi pihak sekolah harus memanfaatkan secara maksimal dengan kerja sama yang baik antar pihak sekolah dan pihak diluar sekolah. Yang dimana peluang ini akan memperkecil ancaman pada butir pertama yaitu persaingan dalam bidang TIK yang belum begitu baik. Ancaman ini dapat diminimalisir dengan peluang tersebut dengan cara tidak hanya infrastruktur saja yang diperhatiakan tapi tenaga pengajar yang mampu juga harus dipenuhi.

Setelah memperoleh semua informasi yang berpengaruh terhadap kelangsunan sekolah, tahp selanjutnya adalah dengan memanfaatkan semua informasi tersebut dengan model kuantitaif perumusan strategi. Pada tahap ini menggunaka Matriks SWOT, karena matriks ini akan menggaambarkan secara jelas bagaimana peluang, ancaman eksternal yang dihadapi sekolah dapat disesuaikan dengan kekuatan dan kelemahan yang dimilikinya.

Tabel 4. Diagram Matriks SWOT

$\begin{array}{lll}\text { IFAS } & \text { KEKUATAN (S) } & \text { KELEMAHAN (W) } \\ & \text { 1) } \text { Pembiayaan } & \text { 1) Keadaan Guru } \\ & \text { 2) } \text { Motivasi guru dan } & \text { 2) Rekrutmen guru dan } \\ \text { Siswa } & \text { staf } \\ \text { EFAS } & \text { 3) } \begin{array}{l}\text { Fasilitas } \\ \text { perpustakaan dan } \\ \text { Lab computer }\end{array} & \begin{array}{l}\text { 3) } \\ \text { Penerimaan siswa } \\ \text { pindahan }\end{array} \\ & \text { 4) } \begin{array}{l}\text { Pendekatan, metode } \\ \text { mengajar guru yang }\end{array} & \end{array}$


PELUANG (0)

1) Kesesuain sarana dan Prasarana Sekolah dengan tuntutan perkembangan IPTEK serta IMTAG

2) Dukungan pemerintah dalam melengkapi sarana dan prasarana

3) Sponsor/perusahaan/ yayasan

4) Tuntutan masyarakat terhadap lulusan yang berkualitas

5) Dukungan orang tua yang tinggi

ANCAMAN (T)

1) Kemajuan Teknologi computer dan informatika

2) Lembaga pendidikan sejenis

3) Persaingan masuk SMP Negeri

4) Lingkungan social sekolah bervariasi

5) Hubungan yang baik antara guru dengan guru ataupun dengan siswa

\section{STRATEGI SO}

1) Terus memotivasi guru dan siswa dalam kegiatan belajar mengajar, dengan dukungan pemerintah dalam melengkapi sarana dan prasarana

2) Terus melanjutkan hubungan baik guru dan siswa diiringi dengan IPTEK dan IMTAG

3) Terus melakukan pendekatan dan metode mengajar yang bervariasi dan berinovasi dalam mengajar agar terus menhasilkan lulusan yang berkualitas

\section{STRATEGI ST}

1) Selalu berusaha dan bekerja keras untuk menjadi yang terbaik di segala bidang baik itu guru, siswa, dalam rangka persaingan dengan sekolah lain.

2) Terus berkreatifitas dan berinovasi dalam kegiatan belajar mengajar

\section{STRATEGI WO}

1) Diharapkan kepada pemerintah untuk tidak hanya memperhatikan sarana dan prasarananyan tetapi pengadaan tenaga pengajar.

2) Adanya dukungan dengan orang tua siswa sehigga dapat membantu sekolah dalam melengkapi sarana sekolah.

\section{STRATEGI WT}

1) Menerimah tenaga guru yang berkompeten dan diharapkan siswa yang berkualitas yang masuk sekolah ini, karena kualitas guru adalah cerminan kualitas siswa.

Dengan mempergunakan tabel factor Internal-Eksternal, dan skala sangat tinggi, tinggi, sedang dan rendah maka kedudukan SMP Negeri 4 Kendari dengan diagram cartesius, maka posisinya dapat diketahui sebagai berikut:

IFAS

Tabel 5. Rangkuman Perhitungan IFAS dan EFAS

3,1 EFAS 3,0


Total Skor kekuatan (S)

Total Skor kelemahan $(\mathrm{W})$

S-W $(1,8-1,3)$
$1,8 \quad$ Total Skor Peluang (O) $\quad 1,95$

1,3 Total Skor Ancaman (T) 1,05

$0,5 \quad$ O-T $(1,95-1,05) \quad 0,9$

Berdasarkan tabel di atas maka nampak bahwa titik koordinat posisi SMP Negeri 4 Kendari pada titik sumbu kekuatan 0,5 dan sumbu peluang 1,1. Untuk lebih jelasnya dapat dilihat dalam diagram cartesius sebagaimana berikut:

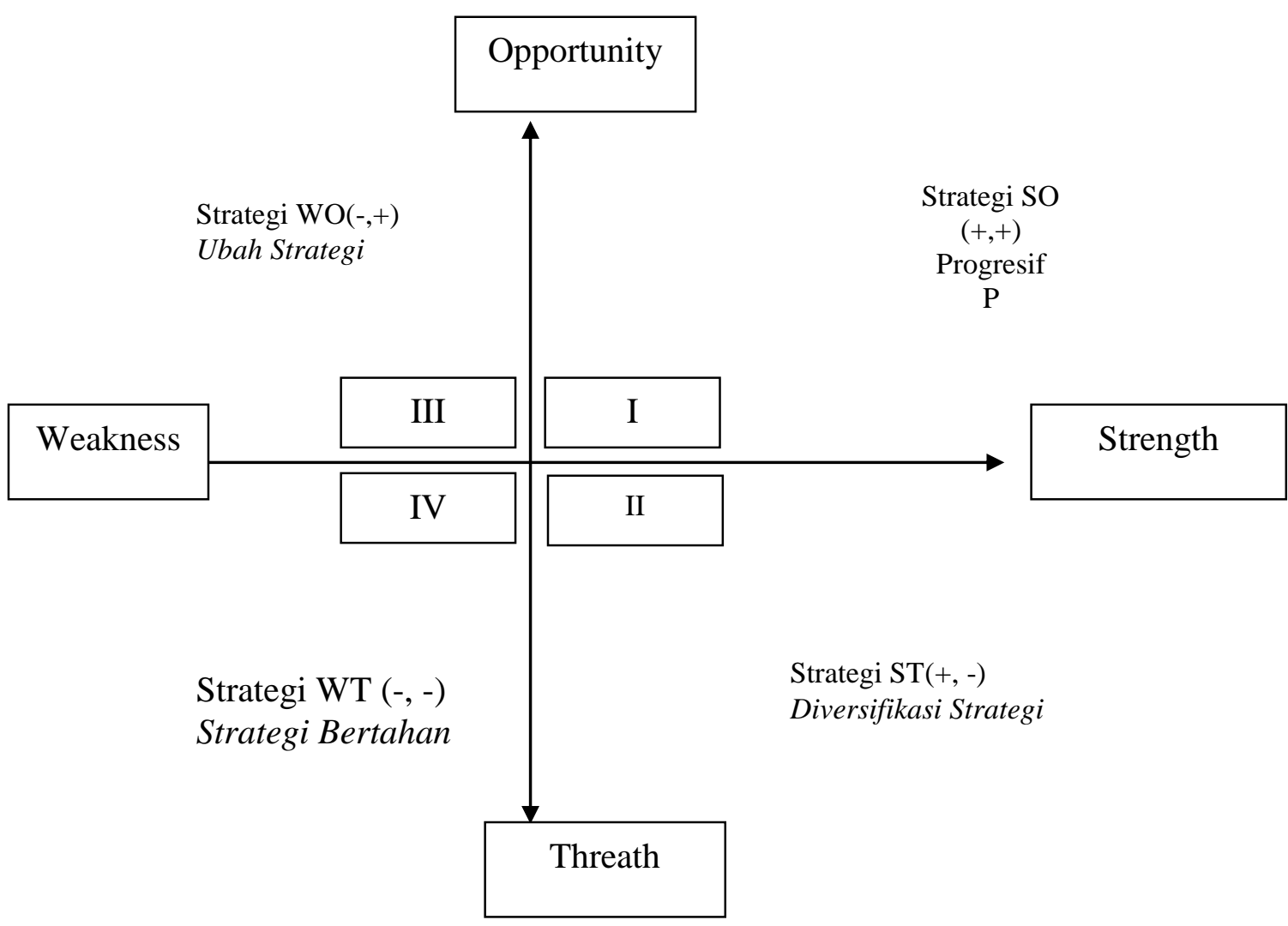

Keterangan:

AFI: 3,1 dengan $(S=1,80)$ dan $(\mathrm{W}=1,30)$ jadi $(\mathrm{S}-\mathrm{W}=1,8-1,3=1,5)$

AFE: 3,00 dengan $(\mathrm{O}=1,95)$ dan $(\mathrm{T}=1,05)$ jadi $(\mathrm{O}-\mathrm{T}=1,95-1,05=0,9)$

Simpulan:

1. Dari perhitungan diatas dapat diuraikan beberapa hal yang berhubungan dengan analisis SWOT di SMP Negeri 4 Kendari yaitu dijelaskan bahwa kurangnya aspek kekuatan terbukti dari AFI (analisis factor internal) berupa kekuatan dengan poin 1,80 dari skala $1 \mathrm{~s} / \mathrm{d} 4$ adalah angka yang masih kurang untuk kategori kekuatan.

2. Poin untuk aspek kelemahan sebesar 1,30 , selisih $S$ dan $T$ ini cukup jauh yakni 1,5. Hal ini dapat dijadikan acuan bagi pihak sekolah untuk menetapkan kebijakan yang baru dan lebih kreatif guna meningkatkan poin kekuatan sekolah secara maksimal agar kelemahan sekolah dapat diminimalisir. 
3. Pada analisis AFE (analisis factor eksternal) SMP Negeri 4 Kendari mempunyai poin peluang sebesar 1,95 angka ini jika dilihat dari skala 1- 4 masih belum bisa dikatakan baik. Hal ini dapat dijadikan pelajaran bagi sekolah untuk lebih cerdas dalam memanfaatkan peluang dan mencari peluang lain yang lebih baik dalam rangka memajukan sekolah.

4. Pada asepek ancaman 1,05 adalah angka yang melebihi standar skala untuk kategori ancaman yaitu jika poin 1 maka ancaman tersebut besar. Dengan demikian antara peluang dan ancaman hanya berselisih 0,90. Masih banyak hal yang harus diusahakan sekolah agar poin peluang bisa lebih besar daripada poin ancaman.

5. Keadaan SMP Negeri 4 Kendari ini belum bisa dikatakan baik setelah dilakukan analisis SWOT masih banyak hal-hal yang harus diperbaiki guna memperoleh keadaan yang stabil sehingga dapat mengambil keputusan yang tepat untuk kemajuan sekolah.

Dari hasil penggabungan analisis SWOT dapat dikembangkan menjadi Strategi S-O, strategi W-O, Strategi S-T, dan Strategi W-T, Yakni:

1. Strategi S-O

Strategi S-O merupakan strategi yang digunakan untuk memanfaatkan peluang dengan mendayagunakan kekuatan yang dimiliki sekolah, yaitu: Aspek Kesiswaan, Tenaga Pendidik, Kependidikan dan Pelatihan serta Sarana dan Prasarana yang memadai harus dimanfaatkan semaksimal mungkin. Hal ini agar semakin menarik minat masyarakat secara umum serta dapat meningkatkan mutu dan eksistensi sekolah. Kemudian elemenelemen tersubut juga harus dikelola dengan baik agar dapat menjawab kebutuhan pendidikan.

2. Strategi W-O

Strategi W-O adalah strategi yang dapat dipakai untuk mengurangi kelemahan dengan melihat peluang yang ada. Strategi WO yakni: Kurikulum 2013 yang memiliki berbagai kendala dalam penerapannya harus dikelola secara maksimal, dapat menjadi peluang untuk meraih prestasi dalam berbagai bidang baik akademik maupun non akademik.

3. Strategi S-T

Strategi S-T adalah strategi yang disusun untuk mengurangi dan mengantisipasi ancaman dengan mendayagunakan kekuatan yang dimiliki sekolah. Strategi S-T yakni kekuatan sekolah berupa aspek kesiswaan, sarana dan prasarana, tenaga pendidik, kependidikan harus dapat dimanfaatkan semaksimal mungkin untuk mengurangi ancaman perkembangan IPTEK yang dapat membawa dampak negatif bagi siswa.

4. Strategi W-T

Strategi W-T adalah strategi yang dibuat untuk mengurangi kelemahan dan ancaman yang dihadapi oleh sekolah, yakni kelemahan yang ada pada sekolah adalah belum optimalnya implementasi kurikulum 2013. Sedangkan untuk mengantisipasi ancaman berupa dampak negatif perkembangan iptek, sekolah, dapat mengadakan pembinaan siswa-siswi terkait dampak negatif yang diterima dari perkembangan internet. Selain pembinaan siswa, sekolah harus memberi aturan maupun tata tertib sekolah untuk menggunakan internet, agar siswa mengerti aturan yang baik dalam penggunaan internet, ancaman yang ada itu dalam hal penataan tata 
ruang, karena kita memiliki lahan yang sangat luas sekali dan jika kita tidak tata dengan baik maka bisa menjadi ancaman, dan juga jumlah siswa yang sangat banyak.

Setelah mengetahui strategi yang diperoleh dari hasil penggabungan analisis SWOT sehingga menjadi strategi S-O, strategi W-O, strategi S-T, dan strategi W-T, maka akan melalui tahap implementasi. Implementasi strategi yang dimaksud adalah melambangkan atau dapat dikatakan mengoperasionalisasikan strategi ke dalam manajemen maupun organisasi sekolah. Adapun strategi yang diimplementasikan ke dalam manajemen maupun organisasi sekolah adalah:

1. Aspek kurikulum yang tertuang dalam Renstra kurikulum merupakan pembenahan bagi SMP Negeri 4 Kendari. Sehingga kurikulum dalam program untuk menjawab kebutuhan Pendidikan dengan terus mengupdate bagaimana proses RPP yang ideal, tentunya setelah kita mendapatkan RPP yang ideal kemudian kita bandingankan dengan RPP yang ada, kemudian kita rencanakan bagaimana RPP guru yang inovatif dapat sama dengan RPP yang ideal saat ini. Kelemahannya ada di lapangan tergantung kondisi guru-guru yang ada dan bagaimana kita mencari kelemahan itu agar dapat diseleaikan dan dapat dijadikan peluang bagi sekolah untuk meningkatkan prestasi akademis maupun non akademis siswa.

2. Sarana dan prasarana yang dimiliki SMP Negeri 4 Kendari sudah digunakan sesuai fungsinya sehingga mampu mengangkat hasil belajar siswa.

3. Kekuatan sekolah berupa aspek tenaga pendidik, kependidikan dan pelatih dapat mengurangi ancaman perkembangan IPTEK yang dapat membawa dampak negatif bagi siswa.

4. Untuk mengantisipasi ancaman berupa dampak negatif perkembangan internet, sekolah dapat mengadakan pembinaan siswa, sekolah harus memberi aturan maupun tata tertib sekolah untuk menggunakan internet, agar siswa tahu aturan yang baik dalam penggunaan internet.

Indikator mutu pendidikan sekolah dapat dilihat dari kelengkapan sarana dan prasarana KBM, guru, siswa serta mutu lulusan. Prioritas program dalam peningkatan mutu pendidikan tahun 2016/2017- 2020/2021, antara lain:

1. Intrakurikuler

a. Intensifikasi pelaksanaan pendekatan ketrampilan proses, analisa ulangan harian, perbaikan dan pengayaan dan ketuntasan belajar.

b. Mendayagunakan buku pelajaran wajib dan alat pelajaran serta alat peraga

c. Meningkatkan efektifitas dan efesiensi KBM.

d. Meningkatkan pelaksanaan praktikum IPA dan perpustakaan

e. Supervisi dan pembinaan guru / karyawan.

f. Menambah jam pelajaran pada beberapa mapel Ujian Nasional, baik dalam kegiatan intrakurikuler maupun ekstrakurikuler.

2. Indikator keberhasilan pelaksanaan program diharapkan :

a. Adanya peningkatan rata-rata Ujian Nasional, output, dan input.

b. Adanya peningkatan Ujian Nasional dari tahun ketahun.

c. Jumlah lulusan banyak yang diterima di jenjang selanjutnya.

d. Adanya siswa yang berprestasi diluar bidang akademis

e. Menjadi warga negara yang baik berdasarkan tujuan pendidikan nasional 
3. Pengembangan non akademik diprioritaskan pada sarana dan prasarana yang menunjang KBM dan penampilan sekolah secara umum seperti:

a. Perawatan komputer dan laboratorium

b. Tambahan buku perpustakaan ( fisik)

c. Tambahan ruangan untuk pelaksanaan ujian nasional

d. Menyelesaikan rehab kelas

4. Kegiatan ekstrakurikuler lebih menekankan pada pengembangan minat, bakat siswa berdasarkan kegiatan ekstra kurikuler meliputi:

a. Pramuka,

b. Palang merah remaja (PMR)

c. Drumband, kesenian

d. Olahraga

e. Karya ilmiah remaja (KIR).

Monitoring merupakan kegiatan yang bertujuan untuk mengetahui apakah program sekolah berjalan sebagaimana yang direncanakan, apa hambatan yang terjadi dan bagaimana cara mengatasi masalah tersebut jadi menekankan pada pemantauan proses pelaksanaan program. Sedangkan evaluasi merupakan kegiatan yang bertujuan untuk mengetahui apakah program sekolah mencapai sasaran yang diharapkan jadi menekankan pada aspek hasil. Adapun pelaksana monev secara internal adalah kepala sekolah dan wakil kepala sekolah sedangkan secara eksternal Dinas Pendidikan dan pemerintah. Komponen utama monitoring dan evaluasi, diantaranya:

1. Komponen Input

a. Aspek tenaga kependidikan : Kepala Sekolah, Guru dan Karyawan

b. Aspek Kesiswaan : Kondisi siswa dan prestasi siswa

c. Aspek sarana prasarana

d. Aspek peran masyarakat

2. Komponen proses

a. Aspek Kurikulum dan bahan ajar

b. Aspek proses belajar mengajar

c. Aspek penilaian

d. Aspek menejemen dan kepemimpinan

3. Komponen Output

a. Aspek prestasi belajar siswa

b. Aspek prestasi Guru dan Kepala Sekolah

c. Aspek pretasi sekolah

Manfaat besar dari manajemen strategi adalah memberi peluang bagi organisasi dalam pemberdayaan individual. Pemberdayaan adalah tindakan memperkuat pengertian karyawan mengenai efektivitas dengan mendorong dan menghargai mereka untuk berpartisipasi dalam pengambilan keputusan dan latihan inisiatif serta imajinasi. Penerapan manajemen strategi di dalam penyelenggaraan sistem pendidikan memungkinkan suatu organisasi penyelenggara pendidikan (termasuk di dalamnya sekolah dan departemen pendidikan) untuk lebih proaktif daripada reaktif dalam membentuk masa depan lembaga pendidikan di dunia global dewasa ini. Penerapan konsep berpikir dan bertindak strategik, lembaga pendidikan diharapkan dapat mengawali dan mempengaruhi daripada hanya memberi respons terhadap berbagai tuntutan dan atau aktivitas rutin dan birokratis, namun lebih dari itu, lembaga pendidikan 
harus dapat berusaha keras merencanakan kegiatan-kegiatan strategis, mengimplementasikan, dan mengendalikan segenap operasional kelembagaan untuk mencapai tujuan strategis yang telah dirumuskan.

\section{SIMPULAN}

Faktor lingkungan internal dan eksternal perlu diantisipasi, dipantau, dinilai, dan disertakan sedemikian rupa ke dalam proses pengambilan keputusan eksekutif. Para pengambil keputusan, termasuk didalamnya kepala sekolah maupun pengelola pendidikan lainnya seringkali terpaksa mengalahkan tuntutan kegiatan interen dan eksteren lembaga pendidikan demi melayani bermacam kepentingan seperti urusan rutin, dinas, harus selalu di bawah petunjuk atau pedoman kerja yang ditetapkan oleh birokrasi tanpa mempertimbangkan kebutuhan eksternal organisasi yang terus berubah, sehingga proses pengambilan keputusan seringkali tidak maksimal dalam menghasilkan keputusan-keputusan strategis. Akibatnya persoalan aktual lembaga pendidikan yang dihadapi tidak dapat terselesaikan secara maksimal.

Pengamatan dan penilaian yang dilakukan secara simultan terhadap lingkungan eksternal dan internal lembaga pendidikan memungkinkan para pengelola pendidikan mampu mengidentifikasi berbagai jenis peluang yang ada untuk dapat merumuskan dan mengimplementasikan berbagai rencana pendidikan secara berhasil. Rancangan yang bersifat menyeluruh ini dapat dilakukan melalui proses tindakan yang dikenal sebagai manajemen strategik. Setelah mengetahui kekuatan dan kelemahan dan merumuskan visi dan misi langkah yang dilakukan kepala sekolah adalah melakukan pengimplementasian terhadap hasil analisis lingkungan internal dan eksternal dengan merumuskan strategi yang disesuaikan dengan hasil analisis. Adapun strategi yang akan dilakukan kepala sekolah adalah: 1) Melakukan pembinaan terhadap siswa dengan memanfaatkan kualitas sumber daya yang cukup memadai dalam hal ini sarana dan prasarana; 2) Kepala sekolah melakukan pembinaan terhadap guru-guru; 3) Melakukan peningkatan prestasi siswa; 4) Menjaga kebersihan lingkungan sekolah; 5) Melakukan pembangunan untuk melengkapi sarana dan prasarana; 6) Melakukan kerjasama dengan berbagai pihak yang dapat mendukung keberhasilan sekolah; 7) Menjaga hubungan baik antar masyarakat sekolah; 8) Mempertahankan dan meningkatkan prestasi sekolah yang telah dicapai; 9) Mengadakan program pelatihan bagi tenaga pendidik dan kependidikan; 10) Mengembangkan program-program sekolah yang telah dijalankan.

\section{REFERENSI}

Akdon (2011). Strategic Management for Educational Management. Bandung: Alfabeta.

Amirullah \& Cantika, S. B. (2000). Manajemen Strategi. Jogjakarta: Garaha Ilmu.

Fred R, D. (2004). Manajemen Strategis: Konsep-konsep (Edisi Kesembilan). PT Indeks Kelompok Gramedia.

Hermawan, A.H. \& Ghazali, D. (2017) Membangun Generasi Unggul Dengan Budaya Literasi Melalui Kepemimpinan Pendidikan, Jurnal Isema. https://doi.org/10.15575/isema.v2i1.4992 
Iskandar, J. (2017). Penerapan Manajemen Strategi dalam Peningkatan Mutu Madrasah. Jurnal Idaarah. Vol. I No. 02 Desember. http://journal.uinalauddin.ac.id/index.php/idaarah/article/view/4270/3932

Muhaimin. (2003). Wacana Pengembangan Pendidikan Islam. Surabaya: Penerbit Pusat Studi Agama, Politik dan Masyarakat.

Siagian, S. P. (2001). Manajemen Strategik. Jakarta: Bumi Aksara.

Solihin, I. (2012). Manajemen Strategik. Bandung: Erlangga.

Sumarsan, T. (2013). Sistem Pengendalian Manajemen: Konsep, Aplikasi, dan Pengukuran Kinerja, Edisi 2. Jakarta Barat: Indeks.

Tangkilisan, H. N. S. (2003). Manajemen Modern untuk SektorPublic. Yogyakarta: Balairung.

Umar, H. (2010). Desain Penelitian Manajemen Strategik. Jakarta: PT. Raja Grafindo Persada.

Yulianti, D. \& Hemawan, D. (2015) Desain Struktur Organisasi Efektif Untuk Mencapai Tujuan Organisasi Publik. Spirit Publik. Vol. 10 No. 1 April. https://doi.org/10.2096/sp.v10i1.900 